\title{
OBEDIENCE PRESSURE VS PEER PRESSURE: AN EXPLANATION OF MUSLIMS' RELIGIOUS ROLE IN BUDGETARY SLACK
}

\author{
Aryan Danil Mirza. BR ${ }^{1^{*}}$ and Kharisa Rachmi Khoirunisa ${ }^{1}$, \\ ${ }^{1}$ Master of Science in Accounting, Faculty of Economics and Business, Universitas Gadjah Mada, \\ Yogyakarta, 55281, Indonesia
}

\begin{tabular}{|c|c|}
\hline ABSTRACT & ARTICLE INFO \\
\hline $\begin{array}{l}\text { Introduction/Main Objectives: The performance of individuals in } \\
\text { organizations is generally evaluated based on their success at achieving } \\
\text { targets. Furthermore, the role of the budget has a major effect on } \\
\text { individual behavior in the preparation of the budget, by allowing } \\
\text { unethical actions (budgetary slack). Background Problems: There are a } \\
\text { few studies that measure the difference in the influence of social pressure } \\
\text { between superiors and peers on individual's behavior in the organiza- } \\
\text { tional budgeting process. On the other hand, there are inconsistencies in } \\
\text { the results of the research into the role of religiosity in the creation of } \\
\text { budgetary slack. Novelty: To explain why people are not influenced by } \\
\text { social pressures to create budgetary slack, we use the Psychological } \\
\text { Reactance Theory. We argue that religiosity is one factor that influences } \\
\text { people in making decisions about participative budgeting. Religiosity is } \\
\text { believed to be able to influence one's personal values, so it impacts on } \\
\text { one's judgment and determination of whether a thing is good or bad. } \\
\text { Research Methods: This study uses an experimental research method on } \\
65 \text { undergraduate accounting students and a 2x2 factorial design } \\
\text { consisting of two factors, social pressure (obedience pressure and peer } \\
\text { pressure) and religiosity (high and low). Finding/Results: The results } \\
\text { show that religiosity is proven to play an important role in the budget } \\
\text { decision-making process, futhermore it minimizes the occurrence of } \\
\text { budgetary slack. Conclusion: Individuals who have high religiosity are } \\
\text { proven to be better able to avoid creating budgetary slack compared to } \\
\text { individuals who have low religiosity, when receiving pressure from } \\
\text { superiors and peers. This result has implications for organizational } \\
\text { stakeholders dealing with employee recruitment or in the organization's } \\
\text { management control system, as religiosity is an important factor that } \\
\text { must be prioritized. }\end{array}$ & $\begin{array}{l}\text { Keywords: } \\
\text { budgetary slack, } \\
\text { religiosity, psychological } \\
\text { reactance theory, social } \\
\text { pressure } \\
\text { JEL Code: } \\
\text { D13, I31, J22, K31 }\end{array}$ \\
\hline
\end{tabular}

\footnotetext{
* Corresponding Author Master of Science in Accounting, Faculty of Economics and Business, Universitas Gadjah Mada, Yogyakarta, 55281, Indonesia. 


\section{INTRODUCTION}

The performance of managers and individuals in organizations is generally evaluated based on their success at meeting the set targets. This causes the role of the budget to have a major effect on individual behavior in the preparation of the budget. As a part of performance management, budget gives impact to performance evaluation. The increase of performance also give increase in compensation. Budget-based compensation plans usually used in providing incentives for subordinates to proposed budgets that allows for unethical actions (Hansen and Mowen, 1999), such as budgetary slack (Hartman and Mass, 2010).

Budgetary slack is the deliberate underestimation of budgeted revenue or the overestimation of budgeted expenses (Hobson, et al., 2011). Subordinates will adjust their productivity to ensure the achievement of the standards set in the target (Young, 1985). Managers generally create budgetary slack because they want to get rewards from the owners, in the form of bonuses, promotions and recognition for their performance achievements. This practice will certainly cause losses for the company in the future. From the accounting perspective, budgetary slack has dangerous consequences for future profits or upcoming costs, it can harm the upper managers' trust in the middle managers because of the actions taken by the middle managers (Huang and Chen, 2010; Kung et al., 2013; Hobson et al., 2011; Gago-Rodriguez \& Naranjo-Gil, 2016).

Palmer (2012) stated that the creation of a social structure and social control by strong organizational agents would not only cause individuals to commit unethical actions, but furthermore it would lead to the institutionalization of violations (mutual fraud). Merchant and White (2017) found that managers who were under strong personal pressure would be willing to take any action to avoid the termination of their employment or to obtain compensation and promotion. Chong and Syarifuddin's research (2010) showed evidence that accountants who experience pressure from their peers tend to make unethical decisions that are detrimental to the company they are work. Niven and Healy (2016) also found that individuals are more likely to engage in unethical behavior when under pressure to fulfill certain goals.

Lord and DeZoort (2001) concluded that social pressure encourages compliance, which is the individual's desire to avoid the negative consequences of being disloyal to someone in a position of higher authority, or of acting against with the wishes of the group. On the other hand, research by Davis, et al. (2006) found that almost half of the participants (48\%) in their experiment created budgetary slack when they were under pressure from their superiors. However, there were still $52 \%$ of the participants who did not create budgetary slack. This condition is interesting; we argue that personal values are the factor that contributed to this issue. Gibson, et al (2011) stated that personal values have a major influence on the decisionmaking process.

Religiosity is one of the personal values that can be considered as an inhibiting factor for the creation of budgetary slack. Individuals who have high religiosity are considered more able to prevent themselves from committing fraud in the company's budgeting process. Gheitani, et al. (2019) stated that religiosity encourages an increase in employees' work attitudes, which ultimately impacts on the employees' performance. Ismail and Rasheed (2019) stated that individuals who have high religiosity are better able to refrain from engaging in unethical actions.

Religiosity is believed to be able to influence one's personal values, which impacts on one's 
personal judgment in the determination of whether something is good or bad (Schouten, Graafland, \&Kaptein, 2014). Religious individuals will be more likely to have an honest attitude and pay more attention to matters relating to their responsibility to society, as a basis for their decision making (Kum-Lung \&Teck-Chai, 2010). Adnan and Sulaiman (2006) found that the more religious a manager was, the lower was his/her tendency to create budgetary slack.

Research by McGuire et al. (2011) also showed that managers who are more religious will choose to report the real income from management activities rather than manipulate the financial statements. Prayudi and Dharmawan (2018) confirmed that religiosity affects individuals when creating budgetary slack. Individuals who have a low level of religiosity are proven to create more budgetary slack than individuals who have a higher level of religiosity. Research by McGuire, et al. (2011) found that religiosity can reduce the intensity of an individual's desire to commit financial reporting fraud.

On the other hand, Weaver and Agle (2002) found no relationship between religiosity and ethical business practices. Kennedy and Lawton (1998) also found no support for this assumption, as they found students who were very religious engaged in more unethical behavior than those who were less religious. Recent research conducted by Mahmudi and Supriyadi (2019) found no significant effect of the level of individual religiosity on unethical actions. Religiosity also does not significantly reduce the relationship between obedience pressure and the intensity of taking unethical actions (cheating). Helmy's research (2018) also failed to find support for religiosity being a factor that influenced an individual's ethical judgment.

Why do inconsistencies occur in measuring the impact of religiosity? El-Menouar (2014) stated this could be due to the inaccuracy of the measurement instruments used, without adjusting them for the context of the religion in question. For example measurement instruments could be used to measure the religiosity of Christians, and are then used for the followers of Islam, without any change in context. This means the role of religiosity may not be measured properly, which could cause the results to be out of context. Therefore several studies (Jana-Masri and Priester, 2007; Huber and Huber, 2012; El-Menouar, 2014; Ismail and Rasheed, 2019; Gheitani, et al. 2019) developed a more contextual measurement scale for measuring religiosity, especially that of Muslims. It is hoped that the development of this instrument can better capture the role of Muslims' religiosity in an organization's budgeting process.

This study aims to see how the influence of an individual's level of religiosity mitigates obedience pressure and peer pressure. We argue that the individual's reason for rejecting the pressure to do any unethical actions is motivated by the personal values he/she adopts, in this case religiosity. This is because, when a person establishes a close relationship with God, then his/her attitude and behavior tends to conform to Sharia law and its regulations (Rahman, et al., 2006).

This study uses an experimental method to examine and explain the causal relationship between social pressure and religiosity toward the creation of budgetary slack. This study uses a $2 \times 2$ factorial design consisting of two factors, social pressure (obedience pressure and peer pressure) and religiosity (high and low). The results of this research successfully validate the impact of differences in the levels of social pressure (obedience pressure and peer pressure) on the creation of budgetary slack. The results of this study also make an important contribution by providing an explanation regarding the role of 
religiosity in eliminating the creation of budgetary slack. Religiosity, which forms a part of a person's personal values, is proven to play an important role as one of the factors that succeeded in reducing the creation of budgetary slack.

\section{LITERATURE REVIEW}

\section{Obedience Pressure Vs Peer Pressure on Budgetary Slack}

Budgetary slack is created when subordinates downplay their abilities or the capabilities of the business units that will be included in the target (Hobson, et al., 2011). Subordinates will reduce their productivity to achieve the minimum standards set in the target (Young, 1985). Managers create budgetary slack because they want to get rewards, in the form of bonuses, promotions and recognition for their individual performance achievements, that are agreed in their contracts. This practice will certainly cause losses for the company in the future.

Palmer (2012) stated that the creation of a social structure and social control by strong organizational agents would not only cause individuals to commit unethical actions, but furthermore it would lead to the institutionalization of violations (mutual fraud). Merchant and White (2017) found that managers who were under strong personal pressure would be willing to take any action to avoid the termination of their employment or to obtain compensation and promotion. Research by Davis, et al. (2006) found that almost half of the participants in their research experiment created budgetary slack when they were under pressure from their superiors, even though they knew that what they did was unethical and detrimental to the company.

Lord and DeZoort (2001) concluded that social pressure encourages compliance, which is the individual's desire to avoid the negative consequences of being disloyal to someone in a position of higher authority, or of acting against the wishes of the group. On the other hand, Chong and Syarifuddin's research (2010) showed evidence that accountants who experience pressure from their peers tended to make unethical decisions that were detrimental to the institution. Niven and Healy (2016) also found that individuals are more likely to engage in unethical behavior when under pressure to fulfill certain goals.

This study aims to see which social pressures (obedience pressure or peer pressure) have the greatest influence in creating budgetary slack.

H1: Individuals who are subject to obedience pressure are more likely to create budgetary slack than individuals who receive peer pressure.

\section{Religiosity on Budgetary Slack}

Religiosity is considered as one of the factors inhibiting the occurrence of budgetary slack. Individuals who are highly religious are considered to be more able to prevent themselves from committing fraud in their company's budgeting process. This is because when a person establishes a close relationship with God, then his/her attitude and behavior tend to conform to Sharia law and its regulations (Rahman, et al., 2006). Gheitani, et al. (2019) stated that religiosity encourages an improvement in employees' work attitudes which ultimately impacts on their performance. Ismail and Rasheed (2019) stated that individuals who are extremely religious are better able to refrain from engaging in unethical actions.

Religiosity is believed to be able to influence one's personal values so that it impacts on one's judgment about the determination of whether a thing is good or bad (Schouten, Graafland, \& Kaptein, 2014). Religious individuals will be more likely to have an honest attitude and pay 
more attention to matters relating to their social responsibilities toward society, as a basis for decision making (Kum-Lung \&Teck-Chai, 2010). Adnan and Sulaiman (2006) found that the more religious a manager was, the lower his/her tendency was to create budgetary slack.

McGuire, et al (2011) found that religiosity can reduce the intensity of an individual's desire to commit financial reporting fraud. McGuire et al. (2011) also found that managers who are more religious will choose to report the real income from their management activities, rather than manipulating the financial statements. Prayudi and Dharmawan (2018) confirmed that religiosity affects the intention of individuals to carry out budgetary slack. Individuals who have a low level of religiosity are proven to create budgetary slack more frequently than individuals who are more religious.

H2: Individuals who have a low level of religiosity have a greater tendency to create budgetary slack than individuals who are more religious, when receiving high or low social pressure.

\section{Interaction Between Social Pressure and Religiosity on Budgetary Slack}

The social influence theory shows that social pressure causes changes in an individual's decision-making preferences. Merchant and White (2017) found that managers who are under strong personal pressure were willing to take any action to avoid the termination of their employment or to get compensation and a promotion. Lord and DeZoort (2001) also concluded that social pressures can lead to compliance; the desire of individuals to avoid the negative consequences of any disloyal interaction with someone who is in a position of higher authority, or of acting against the wishes of the group.
However, the social psychology literature raises the opposite effect to that of the difference motivation theory. The theory of psychological reactance (Brehm and Brehm: 1981) specifically confirms the effort to persuade individuals to carry out certain actions that are counterproductive, because it is a challenge to control individuals. This pressure encourages reactance, so people refuse to take over the challenges posed, and often decides to go in a way that is contrary to "that pressure." This effect occurs as a reaction to the protection of professional or moral principles (Brehm and Brehm 1981; Grover 1993).

This research aims to see how the influence of the individual's level of religiosity mitigates the obedience pressure and peer pressure. We argue that an individual's reason for rejecting the pressure to do unethical actions is motivated by the personal values he/she adopted, in this case religiosity. This is because, when a person have a good attitudes and his/her behavior tend to conform to Sharia law usually he/she has a close relationship with God (Rahman, et al., 2006).

Religiosity is believed to be able to influence one's personal values, which impacts on one's personal judgment in determining whether a thing is good or bad (Schouten, Graafland, \& Kaptein, 2014). Religious individuals will be more likely to have an honest attitude and pay more attention to matters relating to their social responsibilities toward society, as a basis for their decision making (Kum-Lung \&Teck-Chai, 2010). Adnan and Sulaiman (2006) found that the more religious a manager was, the lower their tendency was to create budgetary slack. Ismail and Rasheed (2019) also stated that individuals who are very religious are better able to refrain from engaging in unethical actions.

H3: Individuals who have low religiosity are more likely to create budgetary slack when 
experiencing obedience pressure than individuals who have low religiosity when receiving peer pressure.

The relationship between these variables is explained in the following research model:

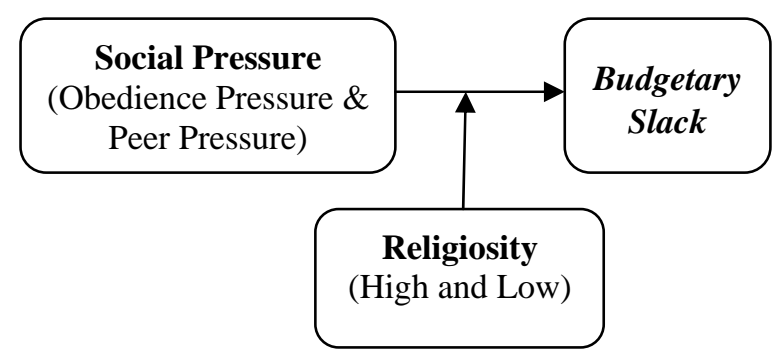

Figure 1. Conceptual Model

\section{METHOD, DATA, AND ANALYSIS}

\section{Experimental Design}

This study used an experimental method to examine and explain the causal relationship between social pressure and religiosity toward the creation of budgetary slack. The experimental method is a research design that investigates a phenomenon by manipulating a situation through various research procedures, and then observing and interpreting the results of the manipulation (Nahartyo, 2013). This study used a 2x2 factorial design consisting of two factors, social pressure (obedience pressure) and religiosity (high and low). The table below illustrates the design of the experiment more clearly.
This study adopted a social pressure case scenario from the research undertaken by Hartman and Mass (2010) into budgetary slack's creation, and the religiosity variable was measured using the instrument of religiosity (Stark and Glock, 1968). We developed the research instrument by some steps. First, we translated the instrument to Indonesian language, and made some adjustments that suitable for Indonesian case. Second, we held a focus group discussion with four people doing research into accounting to discuss the suitability of the instrument for our study's respondents. Third, we undertook a pilot test to examine whether the cases could be understood by the participants. After passing the pilot test, we conducted the real experiment.

The participants in the obedience pressure condition received a treatment in the form of pressure from their superiors to change the budget they drew up, accompanied by the threat of poor performance appraisals leading to dismissal if they did not agree to do it. The participants in the peer pressure condition received a treatment where two of their peers urged the participants to alter the budget so the targets could be more easily achieved, and thus there would be a better opportunity to get bonuses from the company.

Table 1. Experimental Design

\begin{tabular}{lccc}
\hline \multirow{2}{*}{ Factor and Level } & \multicolumn{2}{c}{ Religiosity } \\
\cline { 3 - 4 } & & High & Low \\
\hline \multirow{2}{*}{ Social Pressure } & Obedience Pressure & 16 Participants & 16 Participants \\
& Peer Pressure & 17 Participants & 16 Participants \\
\hline
\end{tabular}




\section{Experimental Participant}

The participants in this study were 75 undergraduate students of the Darmajaya Institute of Informatics and Business who have taken and passed management accounting courses; and $43 \%$ of them had some work experience (employee class). Given these facts, they were considered to have sufficient ability to understand and work on experimental cases concerning budgeting. This study used a simple budgeting case instrument, so accounting student were believed to be sufficiently capable of internalizing and understanding the case. There were six respondents (8\%) who did not fit the religious criteria (non-Muslims). In addition there were four respondents who failed to pass the manipulation check (5\%). So only the data from the remaining 65 participants were processed further.

Table 2. Participants Demographic

\begin{tabular}{llrr}
\hline \multicolumn{2}{c}{ Characteristics } & Frequency & Percent \\
\hline \multirow{2}{*}{ Sex } & Male & 19 & 29.2 \\
& Female & 46 & 70.8 \\
\cline { 2 - 4 } & Total & $\mathbf{6 5}$ & $\mathbf{1 0 0 . 0}$ \\
\hline Age & $20-21$ & 34 & 52.3 \\
& $22-23$ & 31 & 47.7 \\
\cline { 2 - 4 } & Total & $\mathbf{6 5}$ & $\mathbf{1 0 0 . 0}$ \\
\hline GPA & $2.51-3.00$ & 8 & 12.3 \\
& $3.01-3.50$ & 35 & 53.9 \\
& $3.51-4.00$ & 22 & 33.8 \\
& Total & $\mathbf{6 5}$ & $\mathbf{1 0 0 . 0}$ \\
\hline Work & 0 & 37 & 56.9 \\
Experience & $1-2$ & 14 & 21.5 \\
(year) & $3-4$ & 7 & 10.8 \\
& $5-6$ & 7 & 10.8 \\
\cline { 2 - 4 } & Total & $\mathbf{6 5}$ & $\mathbf{1 0 0 . 0}$ \\
\hline
\end{tabular}

\section{Experimental Procedure}

In the initial stage, the participants received an instrument in the form of 18 items of five Likert scale questions to measure the level of their religiosity. After that they received a case instrument on company budgeting, from a company called PT Emerald, Tbk. The participants were told they had worked for the company for two years, as management accountants who were responsible for assisting the finance managers in making strategic and operational decisions, including preparing the budget proposals.

The participants were faced with a situation where the company's budgeting process was underway. They were asked to determine the amount of the budget that would be submitted to the senior management. The participants were placed under one of two types of pressure, which were superiors' pressure or peer pressure, to revise the budget's targets to make them easier to achieve.

The existence of a dilemma in making this decision was the important point in this experiment. The final decision of the participants was how much of a change would they make to the proposed budget. The researcher would see whether the participants' answers contained slack or not, and then calculate the amount of slack created.

\section{RESULT AND DISCUSSION}

Our research hypotheses were tested using two ways ANOVA. This research wanted to examine the difference in influence between obedience pressure and peer pressure. This research also wanted to compare the difference in the levels of religiosity toward the creation of budgetary slack. Finally, the researcher wanted to see if there was a joint interaction between social pressure and religiosity toward budgetary slack. The hypotheses test results are shown in more detail in Table 3 below: 
Table 3. Hypotheses Testing Results (Two Ways ANOVA)

Dependent Variable: BudgetarySlack

\begin{tabular}{lrrrrr}
\hline \multicolumn{1}{c}{ Source } & Type III Sum of Squares & Df & \multicolumn{1}{c}{ Mean Square } & \multicolumn{1}{c}{ F } & \multicolumn{1}{c}{ Sig. } \\
\hline Corrected Model & $4598727,376^{\mathrm{a}}$ & 3 & 1532909,125 & 5,239 & 0.003 \\
Intercept & 22828413,082 & 1 & 22828413,082 & 78,024 & 0.000 \\
SocialPressure & 1604532,485 & 1 & 1604532,485 & 5,484 & $0.022^{* *}$ \\
Religiosity & 2655838,455 & 1 & 2655838,455 & 9,077 & $0.004^{* *}$ \\
SocialPressure * Religiosity & 405838,455 & 1 & 405838,455 & 1,387 & 0.243 \\
Error & 17847426,471 & 61 & 292580,762 & & \\
Total & 45250000,000 & 65 & & & \\
Corrected Total & 22446153,846 & 64 & & & \\
\hline
\end{tabular}

R Squared $=0.205$ (Adjusted R Squared $=0.166$ )

** Sig at $5 \%$ level.

Table 4. Statistical Mean of Budgetary Slack for Each Manipulation Condition

\begin{tabular}{|c|c|c|c|c|c|}
\hline \multirow{2}{*}{\multicolumn{2}{|c|}{ Condition }} & \multirow{3}{*}{$\begin{array}{l}\text { Mean } \\
592,831 \\
\end{array}$} & \multirow{3}{*}{$\begin{array}{r}\text { Std. Error } \\
67,114 \\
\end{array}$} & \multicolumn{2}{|c|}{ 95\% Confidence Interval } \\
\hline & & & & \multirow{2}{*}{$\begin{array}{r}\text { Lower Bound } \\
458,627 \\
\end{array}$} & \multirow{2}{*}{$\begin{array}{r}\text { Upper Bound } \\
727,034\end{array}$} \\
\hline Grand Mean & & & & & \\
\hline \multicolumn{6}{|l|}{ Social Pressure } \\
\hline Obedience Pressure & & 750,000 & 95,620 & 558,796 & 941,204 \\
\hline Peer Pressure & & 435,662 & 94,203 & 247,291 & 624,033 \\
\hline \multicolumn{6}{|l|}{ Religiosity } \\
\hline Low Religiosity & & 795,037 & 94,203 & 606,666 & 983,408 \\
\hline High Religiosity & & 390,625 & 95,620 & 199,421 & 581,829 \\
\hline Social Pressure & Religiosity & & & & \\
\hline \multirow{2}{*}{ Obedience Pressure } & Low Religiosity & 1031,250 & 135,227 & 760,847 & 1301,653 \\
\hline & High Religiosity & 468,750 & 135,227 & 198,347 & 739,153 \\
\hline \multirow{2}{*}{ Peer Pressure } & Low Religiosity & 558,824 & 131,189 & 296,494 & 821,153 \\
\hline & High Religiosity & 312,500 & 135,227 & 42,097 & 582,903 \\
\hline
\end{tabular}

Hypothesis 1 predicted that obedience pressure tended to encourage individuals to create greater budgetary slack than peer pressure did. The results of testing the hypothesis, shown in Table 3, showed a significance of 0.022 (p $<0.05$ ), which meant Hypothesis 1 was supported statistically. Based on the results of this test, the statistically obtained evidence showed that budgetary slack tended to be higher when individuals received obedience pressure compared to peer pressure. The statistical means also support this. The results of this statistical test were also supported by the average budgetary slack (Table 4) which tended to be higher when individuals were subject to obedience pressure $(750,000)$ compared to when they were under peer pressure $(435,662)$. Thus H1 was supported.

This result can be explained by the social influenced theory (Kelman, 1958). This theory explains that individuals can change their behavior to match the demands of their social environment, including pressure from their superiors and colleagues. This result is in line with research by Hartman and Mass (2010), which stated that social pressure can cause individuals to commit unethical actions, including creating budgetary slack. Lord and 
DeZoort (2001) also reached the conclusion that social pressure encourages compliance, which is an individual's desire to avoid the negative consequences of acting against the group's wishes or not being loyal to someone in a position of higher authority. This is what causes subordinates to lose the power to determine their own destinies and actions.

Hypothesis 2 predicted that individuals who had a low level of religiosity would be more likely to create budgetary slack than individuals who had a higher level of religiosity, when they were subjected to obedience pressure and peer pressure. The results of the two ways ANOVA test showed that there was an effect from the differences in the level of religiosity on creating budgetary slack. The two ways ANOVA test results in Table 3 gave a significance result of 0.04 ( $\mathrm{p}<0.05)$ which meant that Hypothesis 2 was statistically supported. The statistical means also support this. Table 4 shows that, on average, budgetary slack tended to be more frequent created by individuals who had a low level of religiosity $(795,037)$, rather than by individuals who had a higher level of religiosity $(390,625)$.

These results provide an explanation that religiosity plays an important role in eliminating budget gaps. This is because religiosity affects one's personal values so that it impacts on one's judgment of whether a thing is good or bad (Schouten, Graafland, \& Kaptein, 2014). Religious individuals are more likely to adopt an honest attitude and pay more attention to matters relating to their social responsibilities toward society, as a basis for their decision making (Kum-Lung \& Teck-Chai, 2010).

These results confirm the research of Adnan and Sulaiman (2006) who also found that the more religious a manager was, the lower their tendency was to create budgetary slack. Research by McGuire, et al (2011) also found that religiosity can reduce the intensity of individuals' intentions to commit financial reporting fraud. Furthermore Prayudi and Dharmawan (2018) also confirmed that religiosity affects individuals who create budgetary slack. Individuals who have a low level of religiosity are proven to create more budgetary slack than individuals who are more religious.

Hypothesis 3 predicted that individuals who had a low level of religiosity and were under obedience pressure would be more likely to create budgetary slack than individuals who had a higher level of religiosity and experienced peer pressure. The results of the two ways ANOVA test showed that there was no interaction between the different forms of social pressure and the different levels of religiosity, with respect to budgetary slack. The two ways ANOVA test results in Table 3 show the significance was $0.243(\mathrm{p}<0.05)$ which meant Hypothesis 3 was not supported statistically. Nevertheless the statistical averages provided support for Hypothesis 3. Table 4 shows that the average of budgetary slack tends to be higher in individuals who are placed under social pressure and have low moral reasoning $(1031,250)$ than individuals who are under less social pressure and have higher moral reasoning (312,500 ).

This result was not what we expected. At first, we thought that the level of religiosity would determine individual considerations when making decisions about what is right or wrong in ethical dilemmas. Individuals who have a high level of religiosity would be able to reduce the intensity of the influence of the social pressure they were experiencing. Meanwhile, for individuals who have a low level of religiosity, when threatened by their superiors they would be realistic about the situation. They would choose to follow the instructions given by their superiors and create budgetary slack, for fear of losing their positions, even though they know 
that their actions were wrong and could be detrimental to the company. But the statistical results did not provide any support for our hypothesis.

This may be due to the fact that individuals, who are under strong personal pressure, are willing to take any action to avoid the termination of their employment or to obtain some compensation or a promotion (Merchant and White, 2017). The amount of pressure applied to an individual results in the individual ignoring the process of ethical judgment based on the personal values he/she holds. Therefore, there is no statistically significant difference.

\section{CONCLUSION AND SUGGESTION}

This research aims to examine the effects of religiosity in mitigating the negative effects of obedience pressure and peer pressure in the creation of budgetary slack. The results of the research show that budgetary slack tends to be higher when individuals face obedience pressure rather than peer pressure. This result is in line with the social influence theory (Kelman, 1958) which stated that individuals can change their behavior to match the demands of their social environment, including pressure from superiors and colleagues. This research contributes to the social pressure literature by validating the research of DeZoort and Lord, 1997; Hartman and Mass, 2010 which stated that social pressure can have an effect on individuals, causing them to change their individual preferences during a budget's decision-making process.

The tendency to create budgetary slack is also proven to be stronger in individuals who have low religiosity compared to individuals who have high religiosity, when subjected to obedience pressure and peer pressure. This is because religiosity affects one's personal values so that it impacts on one's judgment about whether a thing is good or bad (Schouten,
Graafland, \& Kaptein, 2014). The more religious a manager is, the less likely they are to create budgetary slack (Adnan and Sulaiman, 2006).

The results of this study did not succeed in getting statistical support for the interaction between social pressure and religiosity toward budgetary slack. This may be because individuals who are under strong personal pressure may be willing to take any action to avoid the termination of their employment or to obtain compensation or a promotion (Merchant and White, 2017). Therefore, there is no statistically significant difference.

The results of this research successfully validate the impact of differences in the levels of social pressure between obedience pressure and peer pressure on the creation of budgetary slack. The results of this study also make an important contribution by providing an explanation regarding the role of religiosity in eliminating the creation of budgetary slack. Religiosity, which is one part of a person's value system, is proven to play an important role as one of the factors that has succeeded in reducing the creation of budgetary slack. This result also has implications for organizational stakeholders involved in employee recruitment or in an organization's management control system, so they take account of religiosity as an important factor that must be prioritized.

This research has several limitations. First, this study used accounting students as the participants in this experimental research, so there are weaknesses in the external validity related to the generalization of the results. Nevertheless, this study used a simple budgeting case instrument so that business student participants were believed to be sufficiently capable of internalizing and understanding the case. Future research can use participants from professional circles accompanied by more complex and in-depth cases. Future research can 
also consider using other research methods for analyzing social pressures such as surveys and interviews, or combining them with secondary data in order to validate better research results.

Second, this study only measures one personal value, religiosity, for mitigating the occurrence of budgetary slack. Gibson, et al (2011) stated that personal values have a major influence on the decision-making process. Future studies can consider the use of other personal values, such as the locus of control, moral reasoning, and leadership, and then compare which of these personal values are the best for eliminating budgetary slack.

\section{REFERENCE}

Adnan, Mohamed Shayuti and Sulaiman, M. Religion, religiosity and slack creation: some empirical evidence. (2006). AsiaPacific Management Accounting Journal, Vol. 1, No. 1, pp. 49-66.

Brehm, S., \& Brehm, J. (1981). Psychological reactance: A theory of freedom and control. Academic Press. New York.

Chong, V.K. and Syaifuddin. (2010). Escalation of commitment to unprofitable projects: an experimental investigation of the effect of conformity pressure and self-esteem. Accounting, Accountability \& Performance. Vol. 16 No. 1: 1-24.

Davis, Stan, F.T. Dezoort and L. S. Kopp. (2006). The effect of obedience pressure and perceived responsibility on management accountants' creation of budgetary slack. Behavioral Research in Accounting, 18: 1936.

Dezoort, F. T. and A. T. Lord. (1997). A review and synthesis of pressure effects research in accounting. Journal of Accounting Literature 16: 28-85.

El-Menouar, Y. (2014). The five dimensions of Muslim religiosity. Results of an empirical study. Methods, data, analyses, 8(1), 26.

Gago-Rodríguez, S., \& Naranjo-Gil, D. (2016).
Effects of trust and distrust on effort and budgetary slack: an experiment. Management Decision, 54(8), 1908-1928.

Gheitani,

Alborz, Saheb_Imani,_Nader_Seyyedamiri, and Pantea_Foroudi. 2019. Mediating effect of intrinsic motivation on the relationship between Islamic work ethic, job satisfaction, and organizational commitment in banking sector. International Journal of Islamic and Middle Eastern Finance and Management, Vol. 12 No. 1, pp. 76-95.

Gibson, J., Ivancevich, J., \& Konopaske, R. (2011). Organizations: Behavior, structure, processes. McGraw-Hill Higher Education.

Grover, S. L. (1993). Why professionals lie: The impact of professional role conflict on reporting accuracy. Organizational Behavior and Human Decision Processes, 55(2), 251-272.

Hansen,D.R, Mowen.M. (1999). Management Accounting. Fourth Edition. McGraw- Hill International Editions.

Hartman, F. G. H. and V. S. Mass. (2010). Why business unit controllers create budget slack: involvement in management, social pressure and Machiavellianism. Behavioral Research in Accounting, 22 (2): 27-49.

Helmy, Herlina. (2018). The influence of ethical orientation, gender, and religiosity on ethical judgment accounting students. Advances in Economics, Business and Management Research.

Hobson, Jessen L., M. J. Mellondan D. E. Stevens. (2011). Determinants of moral judgements regarding budgetary slack: an experimental examination of pay scheme and personal values. Behaviorial Research in Accounting, 23 (1): 87-107.

Huang, C. L. \& Chen, M. L. (2010). Playing devious games, budget-emphasis in performance evaluation, and attituddes towards the budgetary process. Management Decision, 48(6), 940-951.

Huber, S., \& Huber, O.W. (2012). The Centrality of Religiosity Scale (CRS). Religions, 
3, 710-724.

Ismail, S., \& Rasheed, Z. (2019). Influence of ethical ideology and emotional intelligence on the ethical judgement of future accountants in Malaysia. Meditari Accountancy Research.

Jana-Masri, A., \& Priester, P. E. (2007). The development and validation of a Qur'anbased instrument to assess Islamic religiosity: The religiosity of Islam scale. Journal of Muslim Mental Health, 2(2), 177-188.

Kelman, H. C. (1958). Compliance, identification, and internalization three processes of attitude change. Journal of Conflict Resolution, 2(1), 51-60.

Kennedy, E. and Lawton, L., (1998). Religiousness and business ethics. Journal of Business Ethics, 17, 163-175.

Kung, F. H., Huang, C. L., \& Cheng, C. L. (2013). An examination of the relationships among budget emphasis, budget planning models and performance. Management Decision, 51(1), 120-140

Kum-Lung, C., \& Teck-Chai, L. (2010). Attitude towards business ethics: examining the influence of religiosity, gender and education levels. International Journal of Marketing Studies, 2(1), 225-232.

Lord, A.T. dan F. T. DeZoort. (2001). The impact of commitment and moral reasoning on auditor's responces to social influence pressure. Accounting, Organization and Society, 25: 215-235.

Mahmudi and Supriyadi. (2019). The effects of religiosity on earnings management under obedience pressure. Journal of Economics, Business, and Accountancy, Vol. 22, No. 1.

McGuire, S. T.,Omer, T. C., \& Sharp, N. Y. (2011). The impact of religion on financial reporting irregularities. The Accounting Review, 87(2), 645-647.

Merchant, K. A., \& White, L. F. (2017). Linking the ethics and management control literatures. Advances in Management Accounting, 1-29.

Nahartyo, E., \& Utami, I. (2016). Panduan praktis riset eksperimen. Jakarta: PT. Indeks.

Niven, K., \& Healy, C. (2016). Susceptibility to the 'dark side' of goal-setting: does moral justification influence the effect of goals on unethical behavior? Journal of Business Ethics, 137, 115-127.

Palmer, D. (2012). Normal organizational wrongdoing: A critical analysis of theories of misconduct in and by organizations. Oxford University Press on Demand.

Prayudi, M. A., \& Dharmawan, N. A. S. (2018). Does the Level of Religiosity Determine Budgetary Slacks Behavior as the Result of Superrior's Pressure?. Journal of Economics, Business, and Government Challenges, 1(2), 103-115.

Rahman, N M, Muhamad, N \& Othman, A. S. (2006). The relationship between Islamic work ethics and organisational commitment: a case analysis”. Malaysian Management Review, Vol. 41, No. 1, pp. 79-89.

Schouten, C. M.-v. d. D., Graafland, J., \& Kaptein, M. (2014). Religiosity, CSR attitudes, and CSR behavior: An empirical study of executives' religiosity and CSR. Journal of Business Ethics, 123, 437-459.

Stark, R., \& Glock, C. Y. (1968). American piety: The nature of religious commitment (Vol. 1). Univ of California Press.

Weaver, G. R., \& Agle, B. R. (2002). Religiosity and ethical behavior in organizations: a symbolic interactionist perspective. The Academy of Management Review, 27(1), 7797.

Young, S.M. (1985). Participative budgeting: The effects of risk aversion and asymmetric information on budgetary slack. Journal of Accounting Research,23(2):829-842. 